\title{
MOLECULAR DATA DO NOT CONFIRM THE GRECIAN ANOMALOUS BLUE POLYOMMATUS (AGRODIAETUS) AROANIENSIS (BROWN, 1976) AS A MEMBER OF THE CROATIAN FAUNA
}

\author{
Leona Lovrenčić ${ }^{1}$, Martina Podnar ${ }^{1}$, Martina Ššić ${ }^{1}$, \\ Toni Koren ${ }^{2} \&$ Nikola TvrTKović ${ }^{3}$
}

\author{
${ }^{1}$ Croatian Natural History Museum, Demetrova 1, 10000 Zagreb, Croatia \\ ${ }^{2}$ Croatian Herpetological Society - Hyla, Lipovac I, 7, 10000 Zagreb, Croatia \\ ${ }^{3}$ Alagovićeva 21, 10000 Zagreb, Croatia (e-mail: nikolatvrtkovic71@gmail.com)
}

Lovrenčić, L., Podnar, M., Šašić, M., Koren, T. \& Tvrtković, N.: Molecular data do not confirm the Grecian anomalous blue Polyommatus (Agrodiaetus) aroaniensis (Brown, 1976) as a member of the Croatian fauna. Nat. Croat., Vol. 25, No. 1, 119-129, 2016, Zagreb.

The presence of the Grecian anomalous blue, Polyommatus (Agrodiaetus) aroaniensis (Brown, 1976) in Croatia has been recently published based on external morphology of collected specimens. The aim of this study was to evaluate the credibility of these findings by using DNA barcoding approach as the species exhibit phenotypic variability and can easily be misidentified with morphologically similar species Polyommatus (Agrodiaetus) ripartii. Therefore, we performed a molecular analysis of the mitochondrial gene for cytochrome $\mathrm{c}$ oxidase subunit I (COI) of the samples previously published as $P$. aroaniensis from different localities in Croatia. The results showed that all analysed samples belong to P. ripartii. Additionally, all analysed samples from different Croatian localities (Mt. Mala Kapela, Mt. Lička Plješivica, Mt. Poštak, Mt. Troglav and Mt. Kamešnica) together with previously published population of $P$. ripartii from Mt. Mosor belong to the same Eurasian clade of P. ripartii.

Key words: Polyommatus (Agrodiaetus) ripartii, misidentification, Lycaenidae, Lepidoptera, COI, DNA barcoding

Lovrenčić, L., Podnar, M., Šašić, M., Koren, T. \& Tvrtković, N.: Molekularni podaci nisu potvrdili grčkog plavca Polyommatus (Agrodiaetus) aroaniensis (Brown, 1976) kao pripadnika faune $\mathrm{Hr}$ vatske. Nat. Croat., Vol. 25, No. 1, 119-129, 2016, Zagreb.

Prisutnost vrste Polyommatus (Agrodiaetus) aroaniensis (Brown, 1976), leptira iz porodice plavaca, nedavno je zabilježena u Hrvatskoj na temelju vanjske morfologije prikupljenih jedinki. Cilj ovog rada bio je procijeniti vjerodostojnost tog nalaza korištenjem metode DNA barkodiranja budući da se radi o fenotipski varijabilnoj vrsti koja se lako može zamijeniti s morfološki sličnom vrstom Polyommatus (Agrodiaetus) ripartii. Provedena je molekularna analiza mitohondrijskog gena za citokrom c oksidazu podjedinica I (COI) na uzorcima objavljenih kao vrsta P. aroaniensis s različitih lokaliteta u Hrvatskoj. Rezultati su pokazali da svi analizirani uzorci pripadaju vrsti $P$. ripartii. Također svi uzorci s različitih lokaliteta (Mala Kapela, Lička Plješivica, Poštak, Troglav i Kamešnica) zajedno s ranije objavljenom populacijom P. ripartii s Mosora pripadaju istoj euroazijskoj grupi vrste $P$. ripartii.

Ključne riječi: Polyommatus (Agrodiaetus) ripartii, pogrešna identifikacija, Lycaenidae, Lepidoptera, COI, DNA barkodiranje

\section{INTRODUCTION}

The genus Polyommatus Latreille, 1804 is a large and diverse group of blue butterflies in the family Lycaenidae (Lepidoptera). Agrodiaetus Hübner, 1822 is one of its subgenera 
distributed throughout the Palearctic region. The majority of the Polyommatus species display sexual dimorphism regarding wing colour, with the exception of "brown” type of Agrodiaetus taxa which usually have uniform brown wing upperside in both sexes. Species identification within this group is often difficult based solely on wing morphology, because they are prone to considerable geographic and individual variability in wing pattern (Kolev \& De Prins, 1995; Kandul, 1997, 2004, 2007; Vila et al., 2010; Dincă et al., 2013). However, these species show extreme karyotypic diversity, ranging from n=10 to n=134 (DE Lesse, 1960; LukHTANov \& DANTCHENKo, 2002; LukhtANov et al., 2005; KANDUL et al., 2007), so reliable taxonomic status is usually determined through chromosome number and/or DNA sequencing (Wiemers, 2003; KANDul et al., 2004; LukHTANov et al., 2006; VILA et al., 2010; DincĂ et al., 2013).

In the last century only two species belonging to the subgenus Agrodiaetus have been recorded in Croatia: Polyommatus (Agrodiaetus) damon (Denis \& Schiffermüller, 1775) and Polyommatus (Agrodiaetus) admetus (Esper, 1783) (Lorković, 2009). Polyommatus (Agrodiaetus) ripartii (Freyer, 1830) was added to the List of Croatian butterfly fauna (ŠAšić \& Minoci, 2011) after Koren (2010) and Koren et al. (2011). Specimens of P. ripartii were recorded already in 1997 on Mt. Mosor (Croatia) by Marten Runquist and subsequently analysed with molecular methods which recovered this population within the Euroasian clade of the species (Dincă et al., 2013). After discovery of Polyommatus (Agrodiaetus) aroaniensis (Brown, 1976) south of the town of Gacko in neighbouring Bosnia and Herzegovina (VEROVNIK et al., 2015), the presence of this species in Croatia was recently reported by Koren \& LAuš (2015), but this observation was based exclusively on external morphology of collected specimens (according to Tolman \& Lewington, 2008). It is considered that $P$. aroaniensis can be distinguished from $P$. ripartii by the ground colour of the hindwing underside which is 'medium coffee brown' with reddish hue and without darker marking along the margin and the commonly lacking or indistinct white stripe on the underside of its hindwing (Kolev, 1994; Kolev \& van der Poorten, 1997). With regard to the white stripe, the popular guide by ToLMAN \& LEWINGTON (2008) incorrectly claims that the stripe in question is always absent in P. aroaniensis. However, in terms of wing pattern, $P$. aroaniensis and $P$. ripartii specimens display considerable phenotypic variability regarding the presence, absence or intensity of the white stripe on the hindwings (Kolev, 1994; Kolev \& de Prins, 1995; Kolev \& van der Poorten, 1997; DincĂ et al., 2013; Verovnik et al., 2015). This variability is pronounced even within the same population of $P$. aroaniensis: in the Greek population, from locus typicus of this species (Greece: Mt. Chelmos), the white stripe is present in about 50-60 \% of all specimens (Kolev \& van Der Poorten, 1997). Additionally, the Croatian population of P. ripartii from Mt. Mosor includes specimens with and without the white stripe on the hindwing underside (DincĂ et al., 2013). Male genitalia are a useful diagnostic character for distinguishing $P$. ripartii and $P$. aroaniensis: the Croatian populations of $P$. ripartii should have shorter valvae than P. aroaniensis and P. admetus (Kolev, 1994; Kolev \& De Prins, 1995; Kolev \& van Der Poorten, 1997; Dincă et al., 2013), as well as the number of chromosomes: $P$. ripartii has a chromosome number of $2 \mathrm{n}=90$ (DE Lesse, 1960; WieMERs, 2003) and $P$. aroaniensis $2 \mathrm{n}=48$ (Coutsis et al., 1999).

Available evidence from karyological, molecular and biogeographic studies shows that $P$. ripartii and $P$. aroaniensis belong not to one, as previously believed, but to two species groups which appear as sister clades in all published phylogenetic reconstructions: $P$. ripartii belongs to the so-called admetus group and $P$. aroaniensis to the dolus group (Wiemers, 2003; Kandul et al., 2004, 2007; LuKhtANov et al., 2005; Vila et al., 2010). 
The main goal of the present paper is to evaluate the credibility of the published findings of $P$. aroaniensis by additional analyses of the available voucher specimens (Koren \& LAuš, 2015), as well as to confirm the identification of $P$. ripartii in Lika region including the source of Zrmanja river (Koren, 2010; Koren et al., 2011; TvrtKović et al., 2015; Koren et al., 2015; Koren \& Lauš, 2015) and on the Dinara Massif (Mt. Dinara, Mt. Troglav, Mt. Kamešnica) (Koren \& Lauš, 2013). Due to variability of external morphology and therefore limited reliability of the identification of these two 'brown' Agrodiaetus taxa, specimens were re-identified using the DNA barcoding approach. This molecular method uses a short, standardized region of the mitochondrial gene for cytochrome c oxidase subunit I (COI) for accurate species identification and it accelerates delimitation of morphologically similar species while often revealing cryptic diversity (HeBERT et al., 2003).

\section{MATERIAL AND METHODS}

\section{Material}

Analyzed specimens belonging to the subgenus Agrodiaetus were collected in the period from 2011 to 2015 in several localities in Croatia (Tab.1, Fig.1) as described in Koren \& Lauš $(2013,2015)$, Koren et al. (2015), and TvrtKović et al. (2015), with two additional specimens from Gacko in the south-eastern part of Bosnia and Herzegovina. Taxonomic identification by wing morphology was done according to LAFRANCHIS (2004) and Tolman \& Lewington (2008) for P. admetus and P. damon samples and in accordance

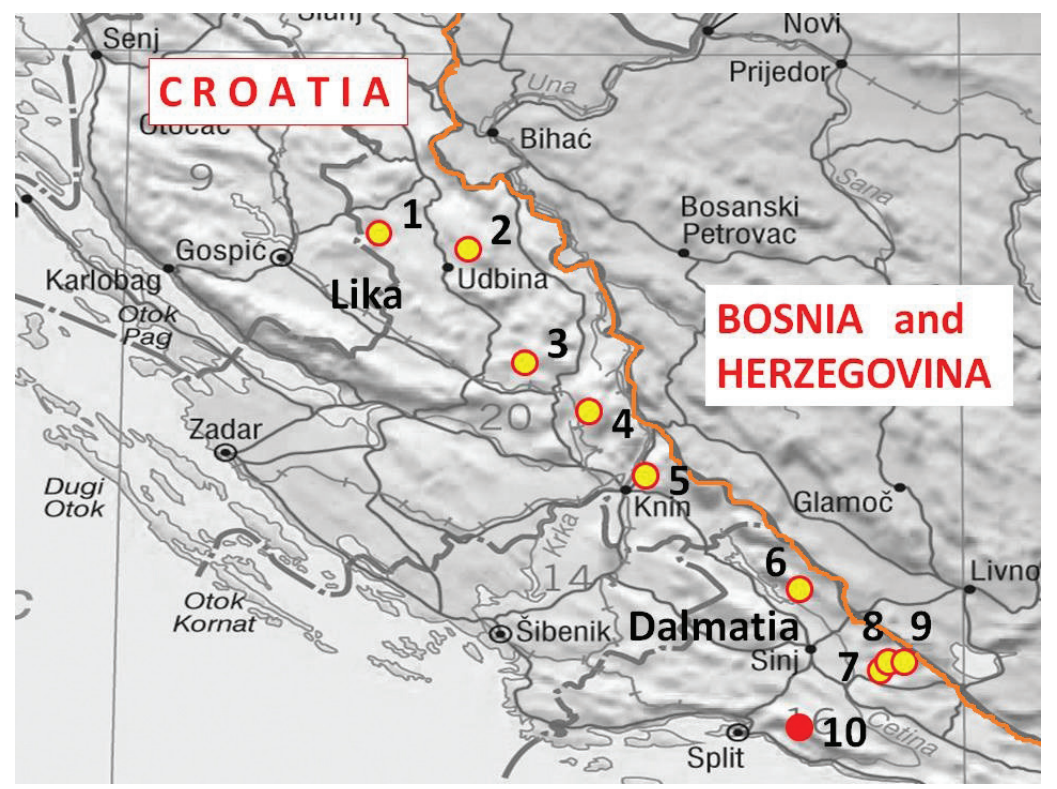

Fig. 1. Map of the surveyed Croatian locations of specimens belonging to the subgenus Agrodiaetus. 1 - Mt. Mala Kapela (Svračkovo Selo); 2 - Mt. Lička Plješivica (Kozja Draga); 3 - Mt. Lička Plješivica (Lisac); 4 - Mt. Poštak; 5 - Mt. Dinara (Kučeljak); 6 - Mt. Troglav (Ravno Vrdovo); 7 - Mt. Kamešnica (Rože); 8 - Mt. Kamešnica (Ćalete), 9 - Mt. Kamešnica (Arkačica). 10 - Locality from Mt. Mosor (Dincă et al., 2013). 
Tab. 1. List of specimens analysed in the present study. Location numbers correspond to the numbers in Fig. 1. Croatian specimens identified as P. aroaniensis by KoREN \& LAUš (2015) are indicated by quotation marks in the species column.

\begin{tabular}{|c|c|c|c|c|c|c|}
\hline & Locality & Species & White & Sex & Publication //leg. /date & Sample \\
\hline 1 & Mt. Mala Kapela: Svračkovo Selo & damon & yes & $\mathrm{f}$ & Tvrtкović et al., 2015 & LDAMK1 \\
\hline 1 & Mt. Mala Kapela: Svračkovo Selo & "aroaniensis" & no & $\mathrm{f}$ & KoREn \& LaUš, 2015 & LARMK1 \\
\hline 2 & Mt. Lička Plješivica: Kozja Draga & ripartii & yes & $\mathrm{f}$ & KoREN \& LaUš, 2015 & LARLP1 \\
\hline 2 & Mt. Lička Plješivica: Kozja Draga & "aroaniensis" & no & $\mathrm{m}$ & Koren \& Lauš, 2015 & LARLP3 \\
\hline 2 & Mt. Lička Plješivica: Kozja Draga & "aroaniensis" & no & $\mathrm{f}$ & Koren \& Lauš, 2015 & LARLP4 \\
\hline 3 & Mt. Lička Plješivica: Lisac & ripartii & yes & $\mathrm{f}$ & TvRTKOvić et al., 2015 & LRLIS1 \\
\hline 3 & Mt. Lička Plješivica: Lisac & ripartii & no & $\mathrm{f}$ & TVRTKOvić et al., 2015 & LARLIS1 \\
\hline 4 & Mt. Poštak & ripartii & no & $\mathrm{f}$ & Koren et al., 2015 & LARPO1 \\
\hline 5 & Mt. Dinara: Kučeljak & admetus & no & $\mathrm{m}$ & N. Tvrtković, 7.07.2011 & LADDIN3 \\
\hline 6 & Mt. Troglav: Ravno Vrdovo & ripartii & yes & $\mathrm{f}$ & N. Tvrtković, 1.08.2014 & LRTRO1 \\
\hline 7 & Mt. Kamešnica: Rože & ripartii & no & $\mathrm{m}$ & N. Tvrtković, 1.08.2014 & LARKAM2 \\
\hline 8 & Mt. Kamešnica: Arkačica (Ćalete) & ripartii & yes & $\mathrm{f}$ & Koren \& Lauš, 2015 & LARKAM3 \\
\hline 9 & Mt. Kamešnica: Arkačica & ripartii & yes & $\mathrm{f}$ & N. Tvrtković, 1.08.2014 & LRKAM2 \\
\hline & B\&H: Gacko: Cernica Village & aroaniensis & no & $\mathrm{m}$ & M. Šašić, 19.07.2013 & LARGA1 \\
\hline & B\&H: Gacko: Cernica Village & ripartii & yes & $\mathrm{f}$ & T. Koren, 19.07.2013 & LARGA2 \\
\hline
\end{tabular}

with Kolev (1994), Kolev \& van der Poorten (1997) and Dincă et al. (2013) in the case of $P$. ripartii and $P$. aroaniensis. Examination of genitalia was performed on three males among the specimens sequenced. The valva length was measured as in Dincă et al. (2013: Appendix, Figure S1). Male genitalia were prepared according to the protocol described in Higgins (1975). For molecular analysis we examined nine specimens of $P$. ripartii with or without a white stripe on the hindwing underside, four specimens published to be $P$. aroaniensis and one specimen of each $P$. admetus and $P$. damon (Tab. 1). Vouchers of all specimens (Tab. 1) are deposited either in the Central collection of Lepidoptera in the Croatian Natural History Museum in Zagreb or in T. Koren's private collection.

\section{DNA extraction, amplification and sequencing}

Total genomic DNA was extracted from ethanol-preserved legs (one or two) using the GenElute Mammalian Genomic DNA Miniprep Kit (Sigma-Aldrich) according to the manufacturer's specifications and eluted in $60 \mu \mathrm{l}$ of elution buffer. A standard 658-bp barcode region of the mitochondrial gene COI was amplified by polymerase chain reaction (PCR) using the primers LepF1 (5'ATTCAACCAATCATAAAGATATTGG3') and LepR1 (5'TAAACTTCTGGA TGTCCAAAAAATCA3') (HEBERT et al., 2004). DNA was amplified in $50 \mu \mathrm{l}$ reactions containing PCR buffer with $1.5 \mathrm{mM} \mathrm{MgCl}_{2}, 0.2 \mathrm{mM}$ dNTPs, $0.4 \mu \mathrm{M}$ of each primer, $1.25 \mathrm{U}$ of Taq polymerase (Promega) and $5 \mu \mathrm{l}$ of eluted DNA. The following 
PCR thermocycling conditions were applied: initial denaturation at $95{ }^{\circ} \mathrm{C}$ for $120 \mathrm{~s}$, followed by 35 cycles of $30 \mathrm{~s}$ at $95^{\circ} \mathrm{C}$ denaturation, $30 \mathrm{~s}$ at $50{ }^{\circ} \mathrm{C}$ annealing, $90 \mathrm{~s}$ at $72{ }^{\circ} \mathrm{C}$, and a final extension step of $7 \mathrm{~min}$ at $72{ }^{\circ} \mathrm{C}$. The PCR products were purified and sequenced using the same primers by Macrogen Inc. (Amsterdam, Netherlands). Sequences were edited and aligned using ClustalW as implemented in BioEdit 7.2.4. (HaLl, 1999).

\section{Phylogenetic analysis}

Data set for phylogenetic analysis involved 97 COI sequences of different taxa of the subgenus Agrodiaetus (P. ripartii, P. aroaniensis, P. nephohiptamenos, P. admetus, P. humedasae, P. dantchenkoi, P. damon) available in GenBank mainly from the studies of Wiemers (2003), Vila et al. (2010) and Dincă et al. (2013) together with our 15 newly sequenced samples which were submitted to GenBank (Tab. 2). The final alignment for COI was 623 bp long and contained 112 sequences representing seven taxa, including Polyommatus icarus as outgroup. Sequences were collapsed to unique haplotypes using FaBox v.1.41 (VILLESEN, 2007) and phylogenetic relationships were inferred using Maximum likelihood (ML) as implemented in MEGA6 (TAmura et al., 2013). MEGA6 was used to select optimal model of sequence evolution (T92+G+I) according to Bayesian Information Criterion (BIC) and to calculate genetic distances with Kimura 2-parameter model of base substitution.

\section{RESULTS AND DISCUSSION}

Phylogenetic analyses of specimens belonging to the subgenus Agrodiaetus based on mitochondrial DNA resulted in the ML tree characterised with three well supported main clades: A, B and C (Fig. 2). Clade A comprises specimens of P. ripartii, P. nephohiptamenos, $P$. admetus and the Croatian samples previously identified as $P$. aroaniensis by Koren \& Lauš (2015). Clade B encompasses specimens of $P$. aroaniensis (from Greece and Bosnia and Herzegovina), P. humedasae and P. dantchenkoi. Clade C contains P. damon specimens. As in the previous study of DincĂ et al. (2013), three main mitochondrial lineages of $P$. ripartii in Europe (Eurasian, Balkan and West European) are comprised within the ripartii clade (clade A). $P$. ripartii is resolved as paraphyletic assemblage with respect to $P$. admetus and $P$. nephohiptamenos, but also with respect to the Croatian specimens previously identified as $P$. aroaniensis. While the identification of $P$. admetus based on external morphology and chromosome number is considered reliable and its species status is not questionable, the taxonomic status of P. nephohiptamenos from Bulgaria and Greece is yet to be properly assessed (WiEmers, 2003; Dincă et al., 2013). The herein obtained DNA sequences of $P$. admetus and $P$. damon clustered within their respective species clades and represent the first published DNA barcodes of Croatian specimens for those two species.

Based on DNA barcode sequence, the specimens of $P$. aroaniensis (from Greece and Bosnia and Herzegovina) and P. ripartii could be unambigously distinguished from each other and identified to a species level. All of the Croatian samples previously identified by Koren \& LAUš (2015) as $P$. aroaniensis were recovered within the Euroasian clade of $P$. ripartii (clade A, Fig. 2), while the sample of P. aroaniensis from Gacko in Bosnia and Herzegovina clustered together with the sample of $P$. aroaniensis from Greece (clade B, Fig. 2). Furthermore, sequence divergences (Kimura two-parameter, K2P distances) between the samples from Croatia previously identified as P. aroaniensis (KoneN \& Lauš, 2015) and the rest of $P$. ripartii ranged from 0 to $2,49 \%$ which is actually a usual range of intraspecific variability within $P$. ripartii (Dinc $\breve{~}$ et al., 2013). The minimal interspecific genetic distances found between $P$. ripartii and P. aroaniensis specimens from Greece (Mt. 


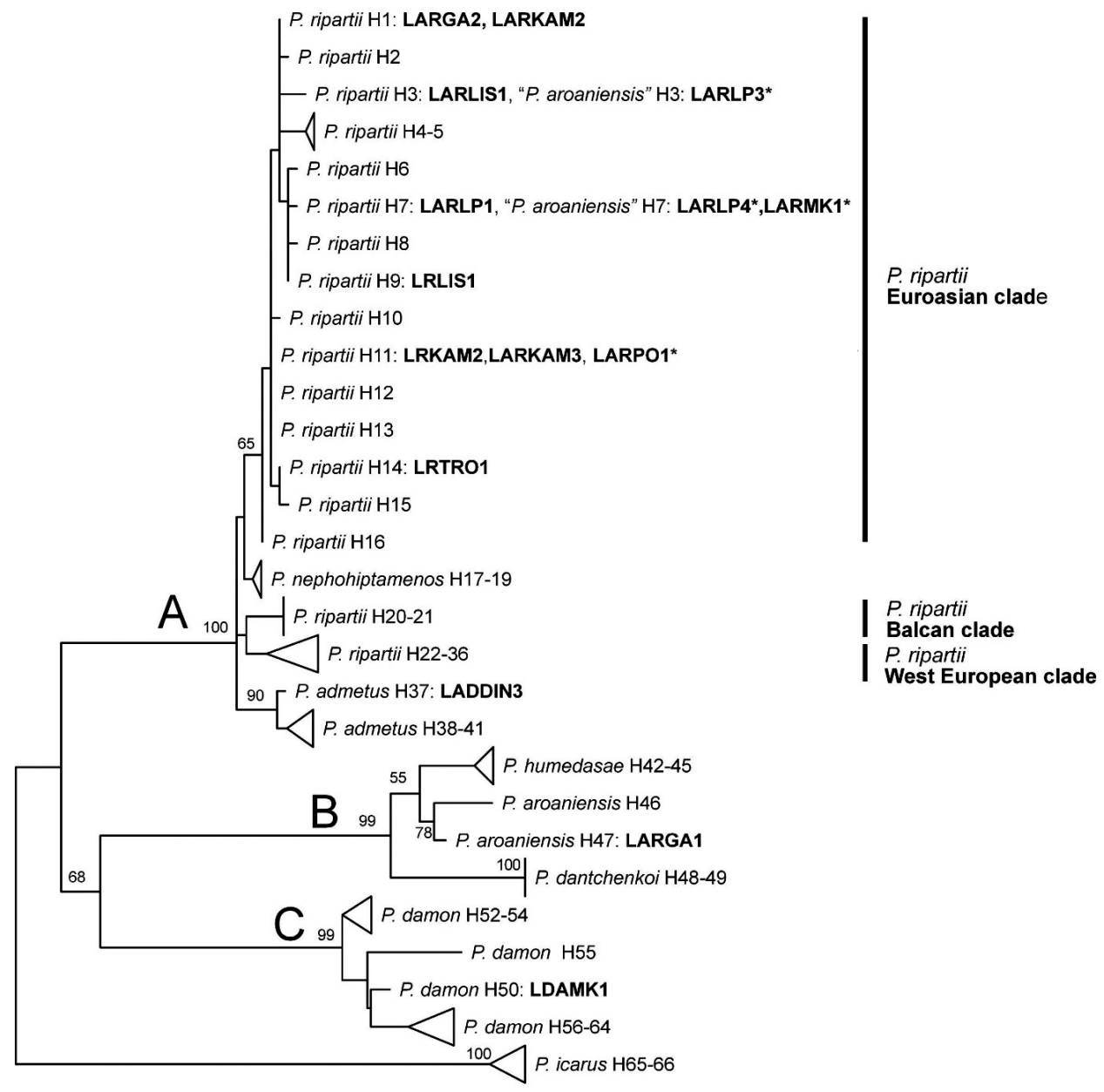

0.02

Fig. 2. Maximum likelihood (ML) tree of Agrodiaetus taxa based on the mitochondrial cytochrome c oxidase subunit I (COI) haplotypes (Tab. 2). Some clades were collapsed to traingles for clarity. ML bootstrap values higher than 50 are shown. Croatian specimens identified as P. aroaniensis based on morphological characters (KoREN \& LAUš, 2015) are indicated by "\#“.

Chelmos) and Bosnia and Herzegovina (Gacko) (6,24 - 7,25\%) were 2.5 times greater than the maximum intraspecific distances within P. ripartii. Therefore, the phylogenetic analysis implies that of all samples barcoded in this study, the sample from Gacko is the only one that actually belongs to $P$. aroaniensis. Based on the phylogenetic lines of evidence and sequence divergence values described above, we conclude that the specimens published as P. aroaniensis by Koren \& LAUš (2015) were misidentified and actually belong to $P$. ripartii. As stated in the paper by Konen \& LAuš (2015) the previous identification of specimens was based entirely on external morphology. 


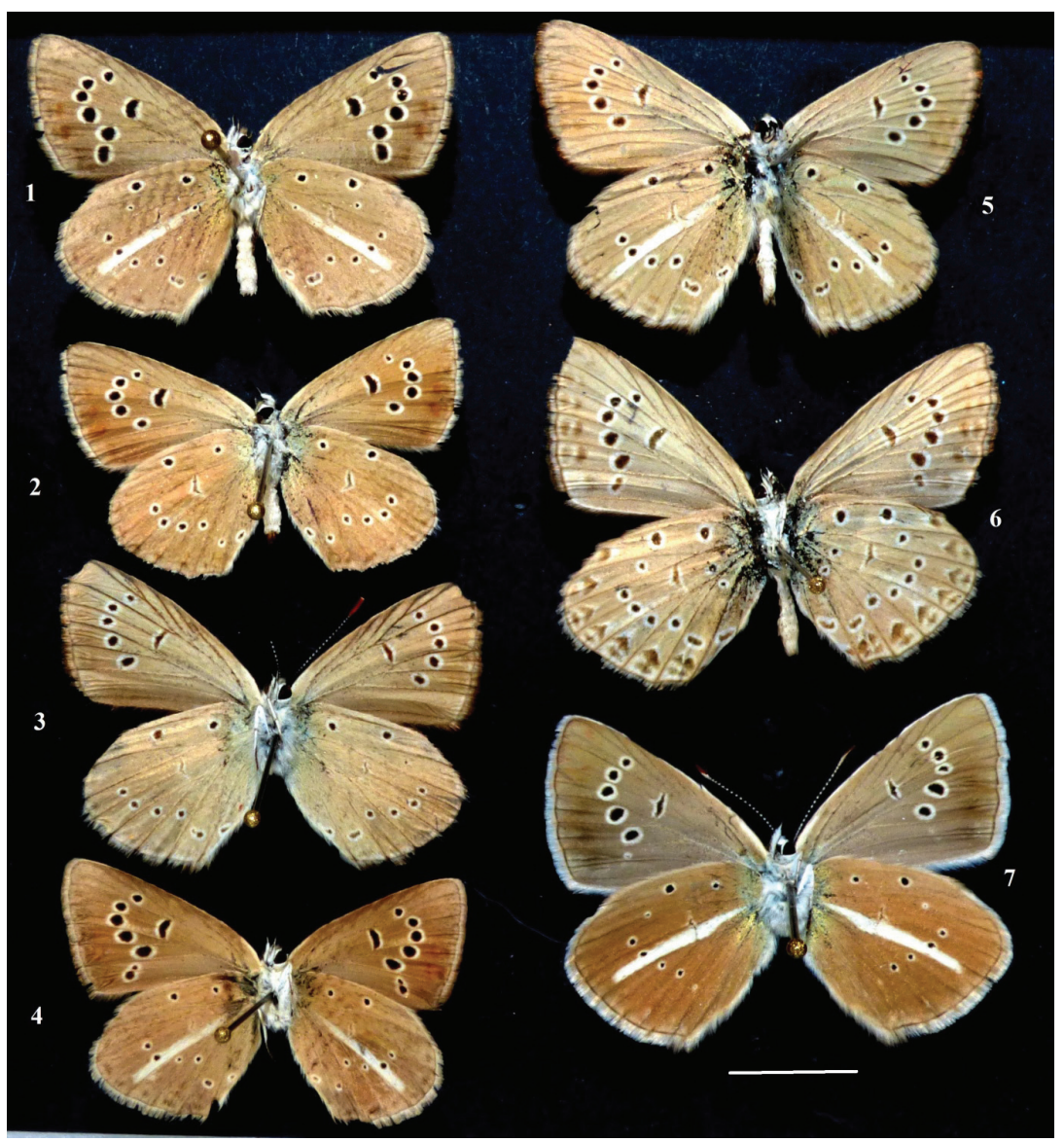

Fig. 3. Ventral view of the several of Croatian specimens of subgenus Agrodiaetus included in the present study. Scale bar is in twenty millimetres. 1 - Mt. Kamešnica (Arkačica), female; 2 - Mt. Kamešnica (Rože), male; 3,4 - Mt. Lička Plješivica (Lisac), females; 5 - Mt. Troglav (Ravno Vrdovo), female; 6 - Mt. Dinara (Kučeljak), male; 7 - Mt. Mala Kapela (Svračkovo Selo), female. $1-5=P$. (A.) ripartii; $6=P$. (A.) admetus; $7=P$. (A.) damon.

It is confirmed that Croatian sequenced specimens of $P$. ripartii exhibit phenotypic variability regarding wing pattern: even within a single population (Mt. Mosor: Dinc $\breve{A}$ et al., 2013; Mt.Troglav, Mt. Kamešnica and Lika: the present paper) there are specimens with and without the white stripe on the hindwing underside, as well as with and without pale marginal markings, rarely with submarginal markings (Fig. 3). Variability of the hindwing underside markings of some sequenced specimens (Fig. 3) is probably larger than variability found on Mt. Mosor (Dincă et al., 2013: Fig. S3). In conclusion, the wing pattern including the presence and absence of white stripe, ground colour of the hindwing and the underside markings should be used with caution as they may lead to serious errors in species identification. Examination of male genitalia confirmed that two male specimens of $P$. ripartii had shorter valvae the single specimen of $P$. aroaniensis from Gacko had longer valvae like in Kolev (1994) and Dincă et al. (2013). 
Tab. 2. List of COI sequences used in this study. Bold - samples sequenced in the present study.

\begin{tabular}{|c|c|c|c|c|}
\hline Taxon & Sample ID & $\begin{array}{c}\text { GenBank } \\
\text { accession number }\end{array}$ & $\begin{array}{c}\text { COI } \\
\text { haplotype }\end{array}$ & Country \\
\hline P. ripartii & RE07-G437 & HM210168 & $\mathrm{H} 1$ & Italy \\
\hline P. ripartii & RVcoll.11-G197 & KC581743 & H1 & Croatia \\
\hline P. ripartii & RVcoll.11-G194 & KC581742 & H1 & Croatia \\
\hline P. ripartii & RVcoll.11-G189 & KC581741 & H1 & Croatia \\
\hline P. ripartii & LARGA2 & KX377637 & H1 & $\mathrm{B} \& \mathrm{H}$ \\
\hline P. ripartii & LARKAM2 & KX377631 & H1 & Croatia \\
\hline P. ripartii & RE07-G436 & HM210167 & $\mathrm{H} 2$ & Italy \\
\hline P. ripartii & LARLP3* & KX377624 & $\mathrm{H} 3$ & Croatia \\
\hline P. ripartii & LARLIS1 & KX377628 & H3 & Croatia \\
\hline P. ripartii & 2005-LOWA-767 & FJ663244 & $\mathrm{H} 4$ & Kazakhstan \\
\hline P. ripartii & 2005-LOWA-67 & FJ663245 & $\mathrm{H} 4$ & Kazakhstan \\
\hline P. ripartii & 2005-LOWA-66 & FJ663246 & $\mathrm{H} 4$ & Kazakhstan \\
\hline P. ripartii & 2005-LOWA-768 & FJ663243 & H5 & Kazakhstan \\
\hline P. ripartii & MW01105 & AY556962 & H6 & Spain \\
\hline P. ripartii & LARLP1 & KX377623 & $\mathrm{H} 7$ & Croatia \\
\hline P. ripartii & LARLP4* & KX377625 & $\mathrm{H} 7$ & Croatia \\
\hline P. ripartii & LARMK1* & KX377626 & H7 & Croatia \\
\hline P. ripartii & RVcoll.11-G193 & KC581732 & $\mathrm{H} 8$ & Croatia \\
\hline P. ripartii & RVcoll.11-G191 & KC581731 & H8 & Croatia \\
\hline P. ripartii & RVcoll.11-G198 & KC581733 & $\mathrm{H} 8$ & Croatia \\
\hline P. ripartii & RVcoll.11-G188 & KC581730 & $\mathrm{H} 8$ & Croatia \\
\hline P. ripartii & RVcoll.09-V363 & KC581729 & H8 & Croatia \\
\hline P. ripartii & LRLIS1 & KX377629 & H9 & Croatia \\
\hline P. ripartii & RV03-H463 & EF104603 & H10 & Spain \\
\hline P. ripartii & RVcoll.11-G195 & KC581740 & H11 & Croatia \\
\hline P. ripartii & RVcoll.09-X021 & KC581739 & H11 & Spain \\
\hline P. ripartii & RVcoll.09-V724 & KC581738 & H11 & Spain \\
\hline P. ripartii & RVcoll.09-V723 & KC581737 & H11 & Spain \\
\hline P. ripartii & RVcoll.08-M934 & KC581736 & H11 & Spain \\
\hline P. ripartii & LRKAM2 & KX377630 & H11 & Croatia \\
\hline P. ripartii & LARPO1* & KX377633 & H11 & Croatia \\
\hline P. ripartii & LARKAM3 & KX377632 & H11 & Croatia \\
\hline P. ripartii & RVcoll.07-C089 & GU677029 & H11 & Spain \\
\hline P. ripartii & RVcoll.08-P614 & HM901664 & H11 & Spain \\
\hline P. ripartii & RVcoll.08-M935 & GU676152 & H11 & Spain \\
\hline P. ripartii & RVcoll.07-F038 & HM901559 & H11 & Spain \\
\hline P. ripartii & RVcoll.08-M697 & GU676158 & H11 & Spain \\
\hline P. ripartii & RVcoll.07-F035 & GU677012 & H12 & Spain \\
\hline P. ripartii & RVcoll.08-P316 & GU676039 & H13 & Spain \\
\hline P. ripartii & RVcoll.11-G192 & KC581744 & H14 & Croatia \\
\hline P. ripartii & LRTRO1 & KX377627 & H14 & Croatia \\
\hline P. ripartii & RVcoll.11-G190 & KC581734 & H15 & Croatia \\
\hline P. ripartii & RVcoll.11-G196 & KC581735 & H15 & Croatia \\
\hline P. ripartii & RVcoll.08-P615 & GU675760 & H16 & Spain \\
\hline P. nephohiptamenos & RVcoll.09-V964 & KC581745 & H17 & Bulgaria \\
\hline P. nephohiptamenos & JC00045 & AY556859 & H18 & Greece \\
\hline
\end{tabular}




\begin{tabular}{|c|c|c|c|c|}
\hline Taxon & Sample ID & $\begin{array}{c}\text { GenBank } \\
\text { accession number }\end{array}$ & $\begin{array}{c}\text { COI } \\
\text { haplotype }\end{array}$ & Country \\
\hline P. nephohiptamenos & JC00046 & AY556860 & H19 & Greece \\
\hline P. ripartii & RVcoll.12-M017 & KC581752 & $\mathrm{H} 20$ & Bulgaria \\
\hline P. ripartii & RVcoll.12-M016 & KC581751 & $\mathrm{H} 20$ & Bulgaria \\
\hline P. ripartii & RVcoll.12-M014 & KC581750 & $\mathrm{H} 20$ & Bulgaria \\
\hline P. ripartii & RVcoll.12-M011 & KC581748 & $\mathrm{H} 20$ & Bulgaria \\
\hline P. ripartii & RVcoll.12-M012 & KC581749 & $\mathrm{H} 20$ & Bulgaria \\
\hline P. ripartii & RVcoll.10-A998 & KC581746 & $\mathrm{H} 20$ & Bulgaria \\
\hline P. ripartii & RVcoll.11-J903 & KC581747 & $\mathrm{H} 20$ & Bulgaria \\
\hline P. ripartii & JC00043 & AY556858 & $\mathrm{H} 21$ & Greece \\
\hline P. ripartii & RE07-G266 & HM210171 & $\mathrm{H} 22$ & France \\
\hline P. ripartii & RVcoll.11-I869 & KC581725 & $\mathrm{H} 22$ & France \\
\hline P. ripartii & RVcoll.11-I703 & KC581724 & $\mathrm{H} 22$ & France \\
\hline P. ripartii & RVcoll.10-B712 & KC581723 & $\mathrm{H} 22$ & France \\
\hline P. ripartii & RVcoll.11-I851 & KC581726 & $\mathrm{H} 23$ & France \\
\hline P. ripartii & RE07-G229 & HM210172 & $\mathrm{H} 24$ & Italy \\
\hline P. ripartii & RE07-G255 & HM210164 & $\mathrm{H} 24$ & Italy \\
\hline P. ripartii & RE07-G254 & HM210163 & $\mathrm{H} 24$ & Italy \\
\hline P. ripartii & RVcoll.12-L128 & KC581721 & $\mathrm{H} 25$ & Spain \\
\hline P. ripartii & RVcoll.08-L945 & GU676213 & $\mathrm{H} 26$ & Spain \\
\hline P. ripartii & RVcoll.12-L137 & KC581722 & $\mathrm{H} 27$ & Spain \\
\hline P. ripartii & RVcoll.12-L140 & KC567884 & $\mathrm{H} 28$ & Spain \\
\hline P. ripartii & RVcoll.12-Q455 & KC581728 & $\mathrm{H} 29$ & Spain \\
\hline P. ripartii & RVcoll.12-Q453 & KC581727 & $\mathrm{H} 29$ & Spain \\
\hline P. ripartii & RV coll.12-L129 & KC567885 & $\mathrm{H} 30$ & Spain \\
\hline P. ripartii & RVcoll.12-L138 & KC581719 & $\mathrm{H} 30$ & Spain \\
\hline P. ripartii & RVcoll.12-L133 & KC567883 & H31 & Spain \\
\hline P. ripartii & RVcoll.11-I888 & KC581720 & $\mathrm{H} 32$ & France \\
\hline P. ripartii & MW01014 & AY556944 & H33 & Spain \\
\hline P. ripartii & MW01072 & AY556957 & H34 & Spain \\
\hline P. ripartii & RVcoll.08-L946 & KC617794 & H35 & Spain \\
\hline P. ripartii & RVcoll.08-L948 & KC617793 & H35 & Spain \\
\hline P. ripartii & RVcoll.08-L892 & GU676220 & H35 & Spain \\
\hline P. ripartii & RVcoll.12-L130 & KC581718 & H36 & Spain \\
\hline P. ripartii & RVcoll.08-L390 & KC581717 & H36 & France \\
\hline P. admetus & LADDIN3 & KX377634 & H37 & Croatia \\
\hline P. admetus & RVcoll.09-V962 & KC581753 & H38 & Bulgaria \\
\hline P. admetus & RVcoll.09-V963 & KC581754 & H39 & Bulgaria \\
\hline P. admetus & JC01014 & AY556867 & $\mathrm{H} 40$ & Greece \\
\hline P. admetus & MW98084 & AY556986 & H41 & Turkey \\
\hline P. humedasae & RE07G191 & HM210169 & $\mathrm{H} 42$ & Italy \\
\hline P. humedasae & MW99605 & AY557128 & $\mathrm{H} 43$ & Italy \\
\hline P. humedasae & MW99591 & AY557127 & $\mathrm{H} 44$ & Italy \\
\hline P. humedasae & RE07G203 & HM210170 & $\mathrm{H} 45$ & Italy \\
\hline P. aroaniensis & JC00040 & AY556856 & $\mathrm{H} 46$ & Greece \\
\hline P. aroaniensis & LARGA1 & KX377636 & $\mathrm{H} 47$ & $\mathrm{~B} \& \mathrm{H}$ \\
\hline P. dantchenkoi & MW99319 & AY557081 & $\mathrm{H} 48$ & Turkey \\
\hline P. dantchenkoi & MW99274 & AY557072 & $\mathrm{H} 48$ & Turkey \\
\hline P. dantchenkoi & MW99276 & AY557073 & $\mathrm{H} 49$ & Turkey \\
\hline P. damon & LDAMK1 & KX377635 & H50 & Croatia \\
\hline
\end{tabular}




\begin{tabular}{|c|c|c|c|c|}
\hline Taxon & Sample ID & $\begin{array}{c}\text { GenBank } \\
\text { accession number }\end{array}$ & $\begin{array}{c}\text { COI } \\
\text { haplotype }\end{array}$ & Country \\
\hline P. damon & MW99613 & AY557131 & H51 & France \\
\hline P. damon & RVcoll.08-L895 & GU676224 & H52 & Spain \\
\hline P. damon & RVcoll.08-L894 & GU676223 & H53 & Spain \\
\hline P. damon & MW99546 & AY557121 & H54 & Turkey \\
\hline P. damon & MW99613 & AY496731 & H55 & France \\
\hline P. damon & RVcoll.07-F023 & GU677042 & H56 & Spain \\
\hline P. damon & RVcoll.08-P326 & HM901317 & H57 & Spain \\
\hline P. damon & RVcoll.08-R289 & GU675795 & H58 & Spain \\
\hline P. damon & RVcoll.08-P001 & GU675971 & H59 & Spain \\
\hline P. damon & RVcoll.08-L167 & GU676405 & H60 & Spain \\
\hline P. damon & RVcoll.08-L994 & HM901305 & H61 & Spain \\
\hline P. damon & RVcoll.07-W228 & GU676752 & H62 & Spain \\
\hline P. damon & RVcoll.08-L230 & GU676393 & H63 & Spain \\
\hline P. damon & RVcoll.09-X513 & HM901513 & H64 & Spain \\
\hline P. damon & RVcoll.08-P629 & HM901325 & H64 & Spain \\
\hline P. icarus & JC00063 & AY556866 & H65 & Greece \\
\hline P. icarus & RVcoll.10-C178 & KM517840 & H66 & Spain \\
\hline
\end{tabular}

Since the herewith presented molecular analysis proves that the Agrodiaetus specimens reported as P. aroaniensis on morphological grounds (Koren \& LAUš, 2015) actually belong to $P$. ripartii, the aforementioned report on the presence of $P$. aroaniensis in Croatia must be discounted. However, as both species occur in Bosnia and Herzegovina, it is impossible to exclude the presence of $P$. aroaniensis in Croatia, even within known localities of $P$. ripartii. Therefore, further identification of this species reporting on new localities and should be confirmed through additional analysis like genital morphometry of the males, molecular and/or karyological data.

Based on the present knowledge, additional findings of $P$. ripartii populations can be expected in Croatia but detailed studies on the biology and ecology of this species are needed to determine its habitat requirements and possibly the need for conservation actions, as the species has a restricted distribution.

Received June 2, 2016

\section{REFERENCES}

De Lesse, H., 1960: Spéciation et variation chromosomique chez les Lépidoptères Rhopalocères. Annales des Sciences Naturelles (Ser. 12) 2(1), 1-223.

Coutsis, J. G., Puplesiene, J. \& De Prins, W., 1999: The chromosome number and karyotype of Polyommatus (Agrodiaetus) ripartii and Polyommatus (Agrodiaetus) aroaniensis from Greece (Lepidoptera: Lycaenidae). Phegea 27(3), 81-84.

Dincă, V., Runquist, M., Nilsson, M., \& Vila, R., 2013: Dispersal, fragmentation, and isolation shape the phylogeography of the European lineages of Polyommatus (Agrodiaetus) ripartii (Lepidoptera: Lycaenidae). Biological Journal of the Linnean Society 109(4), 817-829 + Appendix 1: Supplementary results for the morphological analyses, 4 pp. + Supplementary figures S1, S2 and S3.

HALl, T.A., 1999: BioEdit: a user-friendly biological sequence alignment editor and analysis program for Windows 95/98/NT. Nucleic Acids Symposium Series 41, 95-98.

Hebert, P.D.N., Cywinska, A., Ball, S.L. \& DewaArd, J. R., 2003: Biological identifications through DNA barcodes. Proceedings of the Royal Society of London B: Biological Sciences 270(1512), 313-321.

Hebert, P.D.N., Penton, E.H., Burns, J.M., Janzen, D.H. \& Hallwachs, W., 2004: Ten species in one: DNA barcoding reveals cryptic species in the neotropical skipper butterfly Astraptes fulgerator. Proceedings of the National Academy of Sciences of the United States of America 101(41), 14812-14817. 
Higgins, L.G., 1975: The classification of European butterflies. Collins, London. p.319

KANDUL, N.P., 1997: The karyology and the taxonomy of the blue butterflies of the genus Agrodiaetus HÜBNER (1822) from the Crimea (Lepidoptera: Lycaenidae). Atalanta 28(1-2), 111-119.

Kandul, N.P., Lukhtanov, V.A., Dantchenko, A.V., Coleman, J.W., Sekercioglu, C.H., Haig, D. \& Pierce, N.E., 2004: Phylogeny of Agrodiaetus Hübner 1822 (Lepidoptera: Lycaenidae) inferred from mtDNA sequences of COI and COII and nuclear sequences of EF1- $\alpha$ : Karyotype diversification and species radiation. Systematic Biology 53(2), 278-298.

Kandul, N.P., Lukhtanov, V.A. \& Pierce, N.E., 2007: Karyotypic diversity and speciation in Agrodiaetus butterflies. Evolution 61(3), 546-559.

Kolev, Z., 1994: Two Polyommatus (Agrodiaetus) species new to Bulgaria, with notes on the related Bulgarian taxa (Lepidoptera: Lycaenidae). Phegea 22(2), 61-71.

Kolev, Z. \& De Prins, W., 1995: A new species of the "brown Agrodiaetus" complex from the Crimea (Lepidoptera: Lycaenidae). Phegea 23(2), 119-132.

Kolev, Z. \& van DER Poorten, D., 1997: Review of the distribution of the Balkan endemic Polyommatus (Agrodiaetus) aroaniensis (Lepidoptera: Lycaenidae), with notes on its sympatry with related species. Phegea 25(1), 35-40.

Koren, T., 2010: First finding of Ripart's Anomalous Blue Polyommatus (Agrodiaetus) ripartii (Freyer, 1830) (Lepidoptera, Lycaenidae) in Croatia. Natura Croatica 19(2), 463-467.

Koren, T., BJelić, M., Bozinovska, E., ŠTiH, A. \& Burić, I., 2011: Contribution to the knowledge of butterfly fauna (Lepidoptera: Rhopalocera) of Zrmanja river region, Croatia. Acta entomologica slovenica 19(2), 155-168.

Koren, T. \& Lauš, B., 2013: Dinara Massif - a new hotspot for the butterfly (Papilionoidea) diversity of the Dinaric Arc. Nota Lepidopterologica 36(2), 109-126.

Koren, T. \& Lauš, B., 2015: The Grecian anomalous blue Polyommatus (Agrodiaetus) aroaniensis (Brown, 1976) (Lepidoptera: Lycaneidae) discovered in Croatia, at the north-western edge of its distribution. Natura Sloveniae 17(2), 47-57.

Koren, T., Crne, M., Pavliha, G. \& Trkov, D., 2015: Mountain Poštak, a new hotspot for the Lepidoptera of Croatia (Lepidoptera: Rhopalocera). SHILAP Revista de Lepidopterología, 43 (169), 145-155.

LAFrANCHIS, T., 2004: Butterflies of Europe: new field guide and key, p.351.

LoRкоvić, Z., 2009 (unpublished manuscript from 1954): Rhopalocera fauna of Croatia with special respect to the fauna of Plitvice Lakes. Entomologia Croatica 13(1), 15-78.

Lukhtanov, V.A. \& DANTchenкo, A.V., 2002: Principles of the highly ordered arrangement of metaphase I bivalents in spermatocytes of Agrodiaetus (Insecta, Lepidoptera). Chromosome Research 10(1), 5-20.

Lukhtanov, V.A., Kandul, N.P., Plotkin, J., Dantchenko, A.V., Haig, D., \& Pierce, N.E., 2005: Reinforcement of pre-zygotic isolation and karyotype evolution in Agrodiaetus butterflies. Nature 436(7049), 385-389.

Lukhtanov, V.A., VILA, R., Kandul, N.P., 2006: Rearrangement of the Agrodiaetus dolus species group (Lepidoptera, Lycaenidae) using a new cytological approach and molecular data. Insect Systematics and Evolution 37(3), 325-334.

ŠAšić, M. \& MiнocI, I., 2011: Annotated checklist of Croatian butterflies with vernacular names. Natura Croatica 20(2), 425-436.

Tamura, K., Stecher, G., Peterson, D., Filipski, A. \& Kumar, S., 2013: MEGA6: molecular evolutionary genetics analysis version 6.0. Molecular Biology and Evolution 30, 2725-2729.

Tolman, T. \& Lewington, R., 2008: Butterflies of Britain \& Europe. Harper Collins Publishers, London, p. 384

TVRTKović, N., Verovnik, R., Lovrenčić, L., VuKović, M., \& Šašić, M., 2015: New contributions to the butterfly fauna of Mt. Velebit and the neighbouring area of Lika (Croatia). Natura Croatica 24(2), 281-292.

Vila, R., Lukhtanov, V.A., Talavera, G. \& Pierce, N.E., 2010: How common are dot-like distributions? Taxonomical oversplitting in western European Agrodiaetus (Lepidoptera: Lycaenidae) revealed by chromosomal and molecular markers. Biological Journal of the Linnean Society 101(1), 130-154.

VIlLeSEN, P., 2007: FaBox: an online toolbox for fasta sequences. Molecular Ecology Notes, 7(6), 965-968.

Verovnik, R., Franeta, F., Popović, M. \& Gascoigne-Pees, M., 2015: The discovery of Polyommatus aroaniensis (Brown, 1976) in Bosnia and Herzegovina (Lepidoptera: Lycaenidae). Neva 36(4), 177-180.

Wiemers, M., 2003: Chromosome differentiation and the radiation of the butterfly subgenus Agrodiaetus (Lepidoptera: Lycaenidae: Polyommatus) - a molecular phylogenetic approach. PhD thesis. Bonn, University of Bonn 